Владислав Сотник, кандидат технічних наук, старший науковий співробітник Центральний науково-дослідний інститут озброєння і військової техніки ЗС України ORCID ID 0000-0003-1094-6257 DOI: $10.33099 / 2617-1775 / 2020-01 / 271-279$

\title{
СУТНІСТЬ ТА ОСОБЛИВОСТІ УПРАВЛІНСЬКОЇ КУЛЬТУРИ ВИКЛАДАЧА У ВИЩОМУ ВІЙСЬКОВОМУ НАВЧАЛЬНОМУ ЗАКЛАДІ
}

Досліджено погляди науковиів на сутність поняття «управлінська культура викладача» та ї̈ особливості у вищих військових навчальних закладах. Обтрунтовано основні шляхи підвищення рівня управлінської культури, а також акцентовано увагу на ї̈ структуру та психолого-педагогічні умови реалізації. На основі результатів дослідження сформовано ефективний спосіб формування внутрішньої мотивачії викладача вищих військових навчальних закладів, який полягає в актуалізачії особистого позитивного досвіду.

Ключові слова: викладач; вищі військові навчальні заклади; внутрішня мотивація; напрямки підвищення; особливості; структура; управлінська культура.

Постановка проблеми. В сучасних умовах розвитку та реформування Збройних Сил України все більш актуальною стає проблема підготовки військових керівників 3 розвинутим творчим мисленням, високою управлінською культурою, здатних ефективно вирішувати весь комплекс завдань, що стоять перед ними, а також постійно нарощувати науковотеоретичний потенціал і практичний досвід в умовах бурхливого розвитку засобів сучасної збройної боротьби, змін іiі форм та способів ведення. Актуальність теоретичних і практичних аспектів покращення управлінської культури майбутнього офіцера 3 метою якісного вирішення завдань службової діяльності зумовлена перш за все гуманізацією, гуманітаризацією, демократизацією стосунків у Збройних Силах України. 3 одного боку, об'єктивно зростає значення практичної підготовки офіцера, а 3 іншого значна частина офіцерів не використовує досягнення різних галузей гуманітарних наук у своїй повсякденній діяльності, не вміє застосовувати відповідні форми та методи наукового аналізу й формувати ціннісні та змістовні аспекти управлінської діяльності.

Аналіз останніх досліджень і публікацій. Грунтовний аналіз публікацій вітчизняних та іноземних вчених показує, що управлінська культура офіцера та педагогічні умови займають важливе місце в системі безперервної професійної освіти. Детально дослідження з цієї теми розкривається у працях таких вчених як М. І. Нещадима, О. А. Прохорова, А. О. Кучерявого, О. М. Маслія, I.В. Толока, Р. В. Торчевського та багатьох інших. У педагогічній науці аналізуються й обгрунтовуються значення рушійних сил навчального процесу для ефективного опанування навчального матеріалу такими науковцями: М.А. Данілов, В.І. Загвязінський, А.О. Вітченко, Ю.К. Бабан'ський та інші. Теорію та значення діяльнісного підходу розкривають А.С. Виготський, А.М. Леонтьєв, А.Г. Кузнецова, В.С. Маслов. 
У більшості наукових праць зазначених авторів акцентується увага на теоретичних підходах розвитку управлінської культур викладача в системі безперервної професійної освіти. Однак недостатньо висвітлені аспекти 3 приводу формування управлінської культури майбутніх офіцерів в процесі практичної підготовки.

Мета статті. Основна мета роботи полягає в розкритті сутності управлінської культури викладача та обгрунтування іiі особливостей у вищих військових навчальних закладах.

Виклад основного матеріалу. Аналіз змін в соціальній, інформаційній сферах сучасного суспільства свідчать про необхідність формування в майбутніх офіцерів нової парадигми розуміння значення високої управлінської культури, її взаємозв'язку з професійною та соціокультурною компетентністю. Цей процес повинен грунтуватися на принципах, що включають у себе такі національні та загальнолюдські цінності: свободу української нації, патріотизм, вільне демократичне суспільство, суверенітет і територіальну цілісність держави, цивілізований гуманізм, громадянську злагоду, мир, високу духовність.

Сутність поняття «управлінська культура викладача» розглядалася з різних аспектів багатьма вченими. Так, П. Мілютін визначає управлінську культуру як високий рівень сформованості інтелектуальних, емоційно-вольових, моральних, фізичних якостей, сукупність яких дозволяє вирішувати професійні завдання в сфері управління з високим ступенем ефективності й стабільності [4].

Відносно до досліджень проведених Е. Шейном під управлінською культурою можна розглядати комплекс базових припущень, винайдений, виявлений або розроблений групою для того, щоб навчитися справлятися 3 проблемами зовнішньої адаптації та внутрішньої інтеграції. Необхідно, щоб цей комплекс функціонував досить довго, підтвердив свою спроможність, i тому він повинен передаватися новим членам організації як «правильний» спосіб мислення і почуттів у відношенні згаданих проблем [8].

В. Лапшина називає управлінську культуру системним явищем, яке поєднує відповідні знання, уміння і навички, особистісні якості керівника та його мотиви, що мають прояв у політичній, правовій, організаційній, адміністративній, менеджерській культурі керівника [2].

За твердженням О. Коваленко під управлінською культурою викладача вбачається комплексна, узагальнена характеристика управлінської праці, що відображає якісні риси і особливості керівника освіти, міру і спосіб його творчої самореалізації у різноманітних видах управлінської діяльності, спрямованої на освоєння, передачу і створення цінностей i технологій в управлінні освітнім закладом [1].

Л. Олійник розглядає більш деталізовано розглядає досліджуване поняття, акцентуючи увагу саме на визначенні «управлінської культури офіцера», під яким розуміє поняття, яке передбачає наявність в офіцера специфічних для його професії знань теорії і психології управління, спеціальних умінь і навичок, а також набір особистісних якостей, які забезпечують ефективність його управлінської діяльності під час виконання службових і бойових завдань. 
Деякі вчені зупиняються на розгляді управлінської культури як стилю управління або як сукупного продукту. Так, С. Борнер, Р. Вебер, К. Евард, Х. Грютер, Р. Рютингер та ін. розуміють культуру управління як сукупного способу і продукту управлінської діяльності, феномена, що характеризує культуру організації, знаходимо в іноземній літературі В. Шепель культуру управлінської діяльності розглядає через поняття «культури спілкування», «культури поведінки», а показником управлінської культури вважає стиль управління.

Натомість Л. Онищук [5] - через навчально-інформаційну культуру, яку інтерпретує через призму професійної характеристики, ступеня психологічного, соціального і професійного розвитку, системи знань, переконань цінностей, принципів і способів управлінського досвіду. На думку Г. Сльникової поняття «культура управлінської праці» містить такі різновиди культури, як загальна або загальнолюдська культура, культура політична, правова, естетична, педагогічна $з$ iї багатьма відтінками залежно від типу і специфіки закладу освіти.

Узагальнивши всі наведені твердження можемо зробити висновок, що управлінська культура - це сукупність теоретичних та практичних положень, принципів і норм, що мають загальний характер і відносяться різною мірою до різних аспектів людської діяльності. Це система знань, що обслуговує управлінську практику як культурний феномен, сукупність науки і мистецтва управління, різного роду рекомендацій, узагальнень об'єкта управління, які мають науково-практичну цінність і органічно, системно взаємопов'язані.

Як специфічне професійне явище, управлінська культура являє собою певний рівень оволодіння військовим фахівцем управлінським досвідом людства, ступінь його досконалості в управлінській діяльності, досягнутий рівень розвитку його особистості як керівника i, нарешті, його прагнення до неперервного вдосконалення своєї діяльності. У ній висловлюється ставлення військового фахівця до своєї діяльності, розуміння іï сутності, своєї ролі й свого місця, характер управлінської підготовки, стиль управлінської діяльності, спілкування, поведінки, ставлення до самовдосконалення. Поєднуючи ці взаємозумовлені компоненти особистості, управлінська культура збагачує й розвиває кожен із них до рівня вищого порядку. Управлінська культура виникає i розвивається у процесі управлінської діяльності як необхідна умова ії реалізації [1].

Вивчення практики діяльності викладача у ВВНЗ дозволяє зробити висновок про те, що підвищення рівня управлінської культури можна досягти наступними шляхами:

1. Вивчення рівня сформованості у викладачів ВВНЗ управлінської культури.

2. Надання допомоги викладачам ВВНЗ в адекватній самооцінці досягнутого рівня управлінської культури, розробка індивідуальних планів $\mathrm{i}$ методик.

3. Формування у викладачів ВВНЗ позитивної мотиваційної установки на розвиток управлінської культури. 
4. Обгрунтування значимості управлінської культури для успішної реалізації військово-професійного функціонала.

5. Формування позитивної суспільної думки в офіцерському середовищі військової частини відносно проведеної викладачем ВВНЗ роботи.

6. Вивчення й пропаганда традицій військової частини, що сприяють розвитку у викладачів ВВНЗ офіцерської честі, відповідальності, почуття обов'язку, стійкого інтересу до своєї професійної діяльності.

7. Спонукання викладачів ВВНЗ до роботи із саморозвитку професійних знань, навичок й умінь.

8. Формування у викладачів ВВНЗ ідеалу військового керівника, що володіє високою культурою професійної діяльності.

9. Створення сприятливих умов й можливостей для розвитку управлінської культури й підвищення статусу викладача ВВНЗ.

Складну структуру управлінської культури викладача ВВНЗ можна розділити на чотири основні частини, які визначають, відповідно, його професійну, психолого-педагогічну, моральну й інформаційну культуру. До професійної віднесемо культуру організаційну, ділового спілкування, прийняття рішень і мовну. Психолого-педагогічну культуру визначають такі його складники, як психологічна і педагогічна культури; моральну культуру моральні принципи, життєві цінності, духовність, професійна етика, світогляд і патріотизм; інформаційну - культура роботи 3 інформаційними потоками, моральний ценз, а також культура прийняття рішень.

При цьому важливим складником управлінської культури офіцера $\epsilon$ психолого-педагогічна культура. Її̈ значення пояснюється тим, що по-перше, офіцеру необхідно бути психоаналітиком, розуміти реакцію підлеглого на свої слова, дії й наміри, адекватно реагувати на неї, контролювати свої емоції, бути стійким у стресових ситуаціях. По-друге, він має розуміти психічний стан співрозмовника і відповідно до нього вибирати стиль спілкування. По-третє, офіцерові потрібно керувати морально-психологічним кліматом у підрозділі, максимально сприяти результативній діяльності особового складу [7].

Рівень готовності викладача ВВН3 до сучасної військово-управлінської діяльності в умовах рішення нових професійних завдань може істотно підвищитися при реалізації наступних психолого-педагогічних умов:

1. Модель підготовки викладача ВВНЗ до військово-управлінської діяльності (мета, принципи, зміст, форми організації, методи, засоби) визначається змістом і характером сучасної військово-професійної діяльності.

2. Формування навичок військово-управлінської діяльності здійснюється шляхом iï моделювання в освітньому й різному видах військово-професійної діяльності.

3. Ефективність процесу формування навичок військово-управлінської діяльності забезпечується його цілісністю, послідовністю, взаємозв'язком теоретичної (в освітній діяльності) і практичної (у різних видах військовопрофесійної діяльності) підготовки викладача ВВНЗ на кожному етапі навчання. 
4. Індивідуалізація й диференціація процесу підготовки викладача ВВНЗ до військово-управлінської діяльності здійснюються 3 урахуванням сучасних вимог до такої діяльності, етапів іiі формування, реальних і потенційних можливостей тих, кого навчають.

5. Здійснюється спеціальна й психолого-педагогічна підготовка викладачів в області військово-управлінської діяльності і іiі формування в освітньому процесі ВВНЗ.

Управлінські здатності викладачів ВВНЗ у процесі навчання у ВВНЗ будуть розвиватися більш продуктивно, якщо забезпечувати адекватну самооцінку, стабільність емоційно-вольової сфери, професійну мотивацію до самовдосконалення й інтелектуального зросту особистості майбутнього офіцера, а також удосконалювати систему професіоналізації у ВВНЗ, створювати обстановку творчої конкуренції, об'єктивності оцінки навчальної діяльності й ураховувати іiі результати при призначенні на відповідні посади випускників ВВНЗ [1].

Умови формування культури управлінської діяльності викладача Збройних Сил України визначається характером i рівнем суспільного розвитку, структурою суспільних відносин і міжособистісних зв'язків, рівнем духовної культури, знаннями, досвідом, а також тими обставинами, що характеризують об’єкт управління, суспільство загалом, структуру цього об'єкта, закономірності його функціонування i розвитку та основними принципами управління.

Головним завданням формування та розвитку управлінської культури у викладачів ВВНЗ є забезпечення ефективної освітньої системи, яка складається з педагогічних умов, системи управлінської підготовки (теоретична підготовка, самопідготовка, психофізична підготовка, реальна професійна діяльність), управлінської готовності командира до виконання бойового завдання в сучасний період військового реформування і модернізації вищої військової освіти в контексті євроінтеграційного курсу держави, зокрема, стосовно переходу від модульно-рейтингової до модульно-кредитної системи організації навчання за вимогами Болонського процесу, упровадження нових педагогічних технологій, розроблення й застосування тестових засобів моніторингу процесу формування управлінської компетентності майбутніх офіцерів [6].

Якщо характеризувати сутність соціокультурної підготовки 3 позиції системного аналізу, можна виділити низку її структурних елементів:

1. Визначення, усвідомлення й постановка всієї сукупності цілей і завдань соціокультурної підготовки на всіх етапах професійної підготовки офіцера.

2. Усебічне вивчення й констатація наявного рівня соціокультурної підготовки особи на конкретному етапі життєвого і службового шляху, а також виявлення і врахування основних тенденцій цього розвитку.

3. Комплексне i творче застосування системи методів, засобів, форм i прийомів соціокультурної підготовки, вибір їх оптимального співвідношення 3 урахуванням індивідуальних особливостей викладача ВВНЗ, службових умов його професійної діяльності. 


\section{4. Цілеспрямоване педагогічне спрямування соціокультурного} самовиховання викладача ВВНЗ.

Організаційно-методичні умови формування управлінської культури викладачів ВВНЗ - це заходи освітнього процесу, які забезпечують суб' єктну поведінку курсантів, створюють сприятливі умови для них як повноцінного суб'єкта освітнього процесу. Методично-організаційні умови освітнього процесу ВВНЗ - це застосування професійно орієнтованих методик i дидактичних технологій проведення навчальних заходів, які мають методично обгрунтовано стимулювати розвиток і вдосконалення процесів мислення 3 урахуванням вікових особливостей, військово-професійного та управлінського досвіду, майбутніх кар'єрних перспектив i посадових компетентностей майбутніх офіцерів; забезпечення розвитку основ управлінської культури курсантів у освітній діяльності [3].

До організаційно-педагогічних умов формування управлінської культури викладачів ВВНЗ відносимо:

1. Створення професійно орієнтованого освітнього середовища у ВВНЗ.

2. Обгрунтування змісту навчальної експериментальної дисципліни змісту «Основи управлінської культури», де враховано цілі, завдання, принципи $\mathrm{i}$ специфіку сформованої управлінської культури офіцера; забезпечення міжпредметних зв'язків між навчальними дисциплінами, які створюють сприятливі організаційні та педагогічні умови для цілеспрямованого розвитку управлінської культури викладачів ВВВ.

Викладач ВВНЗ повинен володіти загальнотеоретичними основами дисциплін, які необхідні для управлінської підготовки, науково-методичними та організаційно-педагогічними вміннями. При цьому встановлено, що процес підготовки залежить від організаційно-педагогічних умов. Під організаційнопедагогічними умовами розуміємо чинники, які забезпечують ефективність організації освітнього процесу.

Формування управлінської культури викладача ВВНЗ забезпечується завдяки впровадженню організаційно-педагогічних умов такого процесу. До організаційно-педагогічних умов можна віднести: забезпечення професійної мотивації викладачів ВВН3; орієнтація підготовки основі професії психограми викладача ВВН3 (фрагмент управлінської культури); застосування інформаційного середовища закладу освіти; упровадження інтерактивних методів для формування управлінської культури викладача ВВНЗ.

Для реалізації першої організаційно-педагогічної умови потрібно виходити зі значення мотивації в підготовці викладачів ВВНЗ. Мотивація - це механізм співвідношення особистістю зовнішніх і внутрішніх чинників поведінки, який визначає конкретні форми діяльності. Більш широким є поняття мотиваційної сфери, оскільки вона містить ефективну і вольову сфери особистості, переживання, задоволення потреб [5].

Однак більше уваги звертається все ж таки на внутрішню мотивацію, оскільки вона $\epsilon$ залежною від зовнішньої мотивації й особистих управлінських рис викладача ВВНЗ. Одним із ефективних способів формування внутрішньої мотивації викладача ВВНЗ може бути актуалізація позитивного досвіду, 
застосування його для успішного розв'язання різноманітних завдань, розв'язання різних проблем. Позитивний досвід може бути як власним, так $\mathrm{i}$ опосередкованим через сприйняття інформації з різноманітних джерел, серед яких: художні твори, засоби масової інформації, науково-популярні й науковометодичні видання, спостереження за успішною роботою викладача, більш досвідчених колег [7].

Висновки. Отже, на основі проведеного дослідження можемо зробити висновки про те, що культура військового управління - це сукупність теоретичних і практичних положень, принципів і норм, що мають загальний характер і відносяться певною мірою до різних аспектів службової діяльності. Це, по суті, система знань про управлінську військову практику як культурний феномен, сукупність науки і мистецтва управління, рекомендацій, узагальнення об'єкта управління, що мають науково-практичну цінність і органічно, системно пов'язані між собою. Основною метою аналізу структури культури управління $\epsilon$ вирішення проблеми врахування його результатів у навчальновиховному процесі ВВНЗ як пошук ефективних шляхів і засобів формування професіоналізму викладача ВВНЗ.

Напрями подальших досліджень. Враховуючи проведене дослідження варто відзначити, що в подальших роботах потрібно акцентувати більше увагу на напрямки підвищення управлінської культури викладача у вищих військових навчальних закладах, оскільки вимоги до викладача вже не задовольняється функціонально-орієнтованою i вузькопрофесійною підготовкою. Це пояснюється тим, що важливим компонентом його професійної педагогічної підготовки має стати саме оволодіння основами освітнього (педагогічного) менеджменту, вміннями і навичками саморегуляції і самоуправління, вміннями раціонального використання часу, кваліфікованого опрацювання й використання інформації, здійснення інноваційної професійно-педагогічної діяльності.

\section{ЛIТЕРАТУРА}

1. Коваленко О. Е., О. Брюханова, В. В. Кулешова, І. С. Посохова. Менеджмент освіти: навчальний посібник для студентів вищих навчальних закладів інженернопедагогічних спеціальностей. Харків : ВПП «Контраст», 2008. 68 с.

2. Лапшина В. Л. Формирование управленческой культуры менеджера в условиях становления рыночных отношений: диссертация на соискание научной степени канд. пед. наук : 13.00 .01 . Киев, $1995.143 \mathrm{c}$.

3. Маслій О.М. Формування фахової компетентності майбутніх офіцерів тилу у сфері військово-економічної логістики: автореф. дис. на здобуття наук. ступеня канд. пед. наук: 13.00.04. Хмельницький, 2011. 20 с.

4. Милютин П. Управленческая культура личности и факторы развития. Власть. 2007. № 5. C. 90-93.

5. Онищук Л. А. Гуманізація управлінської діяльності директора школи: монографія / за ред. Л. А. Онищук. Житомир: Полісся, 2002. 324 с.

6. Прохоров О. А. Експериментальна перевірка педагогічних умов та технології готовності майбутніх офіцерів до професійної діяльності на засадах педагогічного менеджменту. Збірник наукових праць Військового інституту Київського національного університету імені Тараса Шевченка. Київ: ВІКНУ, 2010. Вип. № 27. С.322-332. 
7. Торчевський Р.В. Модель розвитку управлінської культури майбутніх магістрів військового управління в системі післядипломної освіти. Вісник Національного університету оборони України. 2012. Вип. 3(28). С.124-129. $336 \mathrm{c}$.

8. Шейн Э. Организационная культура и лидерство. Санкт-Петербург: Питер, 2001.

\title{
REFERENCES
}

1. Kovalenko O. E., O. Briukhanova, V. V. Kuleshova, I. S. Posokhova. Menedzhment osvity: navchalnyi posibnyk dlia studentiv vyshchykh navchalnykh zakladiv inzhenernopedahohichnykh spetsialnostei. Kharkiv : VPP «Kontrast», 2008. $68 \mathrm{~s}$.

2. Lapshyna V. L. Formyrovanye upravlencheskoi kultury menedzhera $\mathrm{v}$ uslovyiakh stanovlenyia rynochnykh otnoshenyi: dyssertatsyia na soyskanye nauchnoi stepeny kand. ped. nauk: 13.00.01. Kyev, 1995. $143 \mathrm{~s}$.

3. Maslii O.M. Formuvannia fakhovoi kompetentnosti maibutnikh ofitseriv tylu u sferi viiskovo-ekonomichnoi lohistyky: avtoref. dys. na zdobuttia nauk. stupenia kand. ped. nauk: 13.00.04. Khmelnytskyi, 2011. $20 \mathrm{~s}$.

4. Myliutyn P. Upravlencheskaia kultura lychnosty y faktory razvytyia. Vlast. 2007. № 5. S. $90-93$.

5. Onyshchuk L. A. Humanizatsiia upravlinskoi diialnosti dyrektora shkoly: monohrafiia / za red. L. A. Onyshchuk. Zhytomyr: Polissia, 2002. 324 s.

6. Prokhorov O. A. Eksperymentalna perevirka pedahohichnykh umov ta tekhnolohii hotovnosti maibutnikh ofitseriv do profesiinoi diialnosti na zasadakh pedahohichnoho menedzhmentu. Zbirnyk naukovykh prats Viiskovoho instytutu Kyivskoho natsionalnoho universytetu imeni Tarasa Shevchenka. Kyiv: VIKNU, 2010. Vyp. № 27. S.322-332.

7. Torchevskyi R.V. Model rozvytku upravlinskoi kultury maibutnikh mahistriv viiskovoho upravlinnia v systemi pisliadyplomnoi osvity. Visnyk Natsionalnoho universytetu oborony Ukrainy. 2012. Vyp. 3(28). S.124-129.

8. Shein E. Orhanyzatsyonnaia kultura y lyderstvo. Sankt-Peterburh: Pyter, 2001. 336 s.

\section{PЕЗЮМЕ}

\section{Владислав Сотник,} кандидат технических наук, старший научный сотрудник Центральный научно-исследовательский институт вооружения и военной техники ВС Украины

\section{Сущность и особенности управленческой культуры преподавателя в высшем военном учебном заведении}

\begin{abstract}
Исследованы взгляды ученых на сущность понятия «управленческая культура преподавателя» $и$ ее особенности в высших военных учебных заведениях. Обоснованы основные пути повышения уровня управленческой культуры, а также акцентировано внимание на ее структуру и психолого-педагогические условия реализачии. На основе результатов исследования сформирован эффективный способ формирования внутренней мотивации преподавателя высших военных учебных заведений, который заключается в актуализации личного положительного опьта.
\end{abstract}

Ключевые слова: преподаватель; высшие военные учебные заведения; внутренняя мотивация; направления повыщения; особенности; структура; управленческая культура.

\section{SUMMARY}

Vladyslav Sotnyk,

Ph.D.(Technical sciences), Senior Researcher (Executive Secretary) Central Research Institute armaments and military equipment 
of the Armed Forces of Ukraine

\section{The essence and features of management culture teacher in higher military educational institution}

The views of scientists on the essence of the concept of "managerial culture of the teacher" and its peculiarities in higher military educational institutions have been investigated. The main ways of increasing the level of managerial culture have been substantiated, and the attention has been paid to its structure and psychological and pedagogical conditions of realization as well. On the basis of the results of the research an effective way of forming the internal motivation of the teacher of higher military educational institutions has been formed, which consists of actualization of personal positive experience.

Key words: teacher; higher military educational establishments; intrinsic motivation; directions of promotion; features; structure; managerial culture. 